\title{
Sharing Responsibility Between Non-State Actors and States in International Law: Introduction
}

\author{
Jean d'Aspremont ${ }^{1,2} \cdot$ André Nollkaemper $^{3}$. \\ Ilias Plakokefalos ${ }^{2} \cdot$ Cedric Ryngaert $^{4}$
}

(C) The Author(s) 2015. This article is published with open access at Springerlink.com

\begin{abstract}
There exists a range of situations where non-state actors and states can possibly share responsibility for their contribution to harmful outcomes, thereby raising a multitude of questions on the determination, content and implementation of responsibility in such a scenario. It may be tempting to adopt an approach whereby a shared responsibility regime involving non-state actors and states draws ex post on the regime put in place by the ILC Articles on Responsibility of States for Internationally Wrongful Acts, especially in connection to the rules of attribution of conduct and attribution of responsibility. Such a model of international responsibility, however, would only work to the extent that addressees are bound by primary
\end{abstract}

This article is part of the collection of articles on Organised Non-State Actors, edited by Jean d'Aspremont, André Nollkaemper, Ilias Plakokefalos and Cedric Ryngaert. The collection was organised with support from the SHARES research project at the ACIL of the University of Amsterdam, the Utrecht Centre for Accountability and Liability Law, and the Leuven Centre for Global Governance Studies. The authors thank Jessica Schechinger for her editorial assistance.

Jean d'Aspremont

J.dAspremont@uva.nl

André Nollkaemper

P.A.Nollkaemper@uva.nl

Ilias Plakokefalos

I.Plakokefalos@uva.nl

Cedric Ryngaert

C.M.J.Ryngaert@uu.nl

1 University of Manchester, Manchester, UK

2 University of Amsterdam, Amsterdam, The Netherlands

3 Faculty of Law, University of Amsterdam, Amsterdam, The Netherlands

4 School of Law of the Faculty of Law, Economics and Governance, Utrecht University, Utrecht, The Netherlands 
norms of international law in the first place. This is certainly not a given in respect of non-state actors. Moreover, non-state actors may differ fundamentally from states, thereby making the transposition of traditional rules of state responsibility artificial and inadequate: their loosely organised, temporary, diverse, illegitimate, or even outright criminal character may militate against applying the classic responsibility paradigm to non-state-state interactions. In view of these limitations, a turn to an ex ante approach to questions of shared responsibility, through standardsetting, has been suggested, and may be cautiously supported in respect of the activities of a number of non-state actors. This, however, is not exclusive to the simultaneous application of ex post and ex ante approaches to shared responsibility.

Keywords Shared responsibility - International law $\cdot$ Non-state actors - States · Wrongful acts · Harmful outcomes · Primary obligations · Standard-setting

\section{Context: Non-State Actors and Responsibility}

The present contribution forms the introduction to a symposium on the question whether and how international responsibility for harmful outcomes is, or should be, shared between non-state actors and states. Apart from this introduction, the symposium consists of four articles, that address respectively the question of shared responsibility from the angle of armed opposition groups ${ }^{1}$ multinational enterprises; ${ }^{2}$ private security companies; ${ }^{3}$ and non-state terrorist actors. ${ }^{4}$

Questions of the responsibility of non-state actors, such as corporations, armed groups, and non-governmental organisations, have long been on the agenda of both policy-makers and international lawyers. It has increasingly been accepted, in the second half of the 20th century, that non-state actors are, or should be, the bearers of international legal obligations. Amplified by regular findings that such obligations are disregarded, demands that legal consequences-especially in terms of responsibility - should be attached to such violations have become more pressing. ${ }^{5}$ In the same vein, the harm which such non-state actors can cause, irrespective of their international obligations, has generated expectations that international law addresses the actions that cause such harm, as well as attaches reparative consequences thereto.

The conceptual and practical difficulties with which policy-makers and international lawyers have been confronted in their attempt to deal with such demands are well known. First, the frameworks of responsibility, which have been designed to address the wrongful conduct of states and international organisations, can only capture a limited part of the conduct of non-state actors which constitutes violations of international law. Likewise, the dominant breach-based approach to responsibility in international law has not made it possible to apprehend those

\footnotetext{
1 Bílková (2015).

2 Karavias (2015).

3 MacLeod (2015).

4 Trapp (2015).

5 See for a discussion Gal-Or et al. (2015).
} 
harmful actions of non-state actors which do not constitute a breach of international legal obligations. What is more, the impugned forms of conduct of non-state actors - whether or not constituting a breach of their obligations-have proved to be complex and composite practices as they often involve the contribution or participation of other actors, including states (and international organisations). Impugned actions by non-state actors rarely fall short of any state (or international organisation's) involvement. They are multi-dimensional from a ratione personae perspective.

\section{Object and Conceptual Premises of the Symposium: Shared Responsibility, Accountability, Regulation and Organised Non-State Actors}

It is against this backdrop that this symposium seeks to provide new insights into the responsibility of non-state actors, especially when their impugned conduct involves, to a larger or lesser extent, acts or omissions of states. ${ }^{6}$ That is, it focusses on situations where a multiplicity of actors contribute towards a single harmful outcome that is not causally divisible. The questions of responsibility examined here can thus be—broadly speaking—qualified as questions of shared responsibility. ${ }^{7}$ For the sake of this symposium, such shared responsibility is envisaged irrespective of whether the actors in question act in concert or independently.

While the symposium does tackle the question whether non-state actors act in breach of international obligations, it takes a broader view and also considers harmful actions by non-state actors in conjunction with states, irrespective of whether these actions constitute a breach of an international obligation by either one of them. The situations examined are thus not only approached from the perspective of shared responsibility stricto sensu but also from the vantage point of shared accountability. The notion of shared accountability refers to situations where multiple actors are held accountable for a certain conduct without this conduct necessarily giving rise to responsibility in the formal and breach-based understanding of the term in international law. Determinations of accountability may for instance be based on standards that apply to non-state actors, but that are not binding as a matter of international law. Accordingly, the conceptual framework within which the question of the shared responsibility of non-state actors is addressed departs from the traditional - and mainstream-law of international responsibility. This departure was considered necessary, as the traditional framework cannot adequately regulate, and ensure accountability for, non-state actors acting in conjunction with states.

Because this symposium grapples with situations where harmful outcomes do not necessarily result from an internationally wrongful act, authors have been invited to espouse not only a traditional, ex post, international responsibility perspective, but

\footnotetext{
6 This symposium does not examine specifically situations where impugned actions involve international organisations, although the findings made in the following contributions will generally apply to those situations as well.

7 See for the conceptual framework for shared responsibility: Nollkaemper and Jacobs (2013).
} 
also a harm-and victim-oriented approach. The latter approach has two dimensions: regulation and accountability. Regulation here pertains to norm-setting processes where one or more actors (whether unilaterally, or through discussions and negotiations with others) agree on standards limiting their scope of action, and allocate 'responsibility' (in an ex ante meaning) to each other with a view to preventing harmful outcomes from materialising. Accountability pertains to the extent to which non-state actors, possibly alongside other actors, are subject to scrutiny and compliance-monitoring with respect to agreed standards, whether or not such standards are legally binding and could thus lead to responsibility. In essence, a non-state actor's accountability refers to an obligation to answer to other actors for its conduct in the light of predetermined review standards. ${ }^{8}$ Such standards may also include legitimate normative expectations of the international community, an extension that allows us to include in the regulation and accountability paradigm situations of non-state actors contributing to harm without being bound by norms of international law, e.g., armed opposition groups or transnational corporations committing human rights abuses that may technically not constitute violations of international human rights law due to the claimed dutybearer's lack of legal personality. ${ }^{9}$

This symposium is eventually predicated on the idea that those non-state actors which exercise some form of public authority and whose action may lead to harmful actions at the international level are usually entities endowed with a relatively integrated and formal structure. Short of an integrated and formal structure, such actors rarely engage in the collective harmful actions which are examined here. This is why throughout this symposium the focus is on organised non-state actors. ${ }^{10}$

\footnotetext{
${ }^{8}$ Compare International Law Association (ILA), Committee on the Accountability of International Organisations, Final Conference Report Berlin 2004, in which the Committee considers, in respect of international organisations, that 'accountability... consists of three levels which are interrelated and mutually supportive: [First level] the extent to which international Organisations, in the fulfilment of their functions are established in their constituent instruments, are and should be subject to, or should exercise, forms of internal and external scrutiny and monitoring, irrespective of potential and subsequent liability and/or responsibility; [Second level] tortious liability for injurious consequences arising out of acts or omissions not involving a breach of any rule of international and/or institutional law (e.g., environmental damage as a result of lawful nuclear or space activities); [Third level] responsibility arising out of acts or omissions which do constitute a breach of a rule of international and/or institutional law (e.g., violations of human rights or humanitarian law, breach of contract, gross negligence...)', see p 5.

9 See as far as armed groups are concerned: 'Report of the Special Rapporteur on extrajudicial, summary or arbitrary executions, Mission to Sri Lanka', UN Doc. E/CN.4/2006/53/Add.5 (27 March 2006), paras. 25-27, holding that armed groups' human rights records are subject to the 'legitimate expectations of the international community'; armed groups must therefore 'accept that insofar as they aspire to represent a people before the world, the international community will evaluate their conduct according to the Universal Declaration's “common standard of achievement"'. See as far as transnational corporations are concerned: Report of the Special Representative of the Secretary-General on the issue of human rights and transnational corporations and other business enterprises, Ruggie J, 'Guiding Principles on Business and Human Rights: Implementing the United Nations "Protect, Respect and Remedy" Framework', UN Doc. A/HRC/17/31 (21 March 2011), with commentary, Commentary to Principle 11: 'The [corporate] responsibility to respect human rights is a global standard of expected conduct for all business enterprises wherever they operate'.

${ }^{10}$ International (intergovernmental) organisations are not considered as organised non-state actors for the sake of this article.
} 
Some formal and structural integration is taken as a prerequisite for the questions of responsibility addressed in this symposium to arise. This being said, compared to states and international organisations, the organised character of non-state actors remains relative. Notably some armed groups have a rudimentary structure. Moreover, non-state actors' organised character need not be permanent. Indeed, it is often the case that non-state actors such as terrorist or armed opposition groups, or even private military companies, are only temporary creatures. It will be shown that the organised character of the non-state actors involved in the situations examined here comes with specific problems with respect to (shared) responsibility, e.g., in terms of attribution and reparation. ${ }^{11}$

\section{Sharing Responsibility and Its Practical Relevance}

While situations giving rise to the question of shared responsibility between nonstate actors and states are certainly not a textbook case, it is not difficult to mention, at this preliminary stage, a range of situations where the question of sharing responsibility can prove pressing. The frequency as well as the likelihood of nonstate actors contributing to harmful outcomes in conjunction with states can be illustrated by the following scenarios: (1) a joint failure of corporations and states to reduce greenhouse gas emissions, which results in environmental degradation and social uprooting through climate change; (2) human rights abuses committed by private military companies to which states have delegated powers; (3) acts of piracy committed by pirates whose acts are condoned or encouraged by (failed) states; (4) violations of economic and social rights committed by public/private partnerships in the energy sector (e.g., through a failure to guarantee the right to water); (5) investors or rating agencies influencing states to take certain decisions that have an adverse impact on the enjoyment of human rights or the protection of the environment; (6) multinational corporations active in the extractive industry sector providing material assistance to repressive governments in order to secure the profitability of mining concessions. In most of these situations, international standards — sometimes of a legally binding nature — are applicable, thereby opening the possibility of responsibility or accountability processes.

\section{Legal and Conceptual Limitations of Mainstream Frameworks}

As was already alluded to above, establishing the responsibility of non-state actors has proved to be a thorny issue, even more so if such responsibility can possibly be shared with states or other actors. Indeed, international law, at least according to the dominant understanding thereof, does not provide a tailored framework on the basis of which non-state actors may be held responsible for contributions to a harmful outcome-whether alone or in conjunction with other actors. This is mainly so because, according to mainstream frameworks of sources and responsibility, it is

11 See notably the contribution of Bílková (2015), Section 2. 
unclear to what extent non-state actors bear obligations under international law, and how responsibility is shared among multiple actors (including states and international organisations). ${ }^{12}$ As a background to the symposium, these difficulties must be briefly recalled here.

Technically speaking, many non-state actors cannot commit internationally wrongful acts which could give rise to their responsibility, for they are not bound by primary norms of international law to begin with. Uncertainty shrouding the binding character of international law for non-state actors explains why one will often naturally try to channel responsibility under the-more classical-frameworks of the responsibility of states on the basis of attribution of the conduct of non-state actors to states, state failure to take proper measures to prevent wrongful non-state conduct, or-more theoretically-attribution of the responsibility of the non-state actor to the state. The International Law Commission's (ILC) Articles on Responsibility of States for Internationally Wrongful Acts (ARSIWA) ${ }^{13}$ give pride of place to the principles governing the attribution of the conduct of non-state actors to states in Articles 5-11, imputing such conduct to states in case of a close proximity between the latter and non-state actor action (e.g., in case a non-state actor exercises elements of governmental authority, or in case a state directs or controls the conduct of a non-state actor). Some primary norms of international law also provide for a state duty to protect against, or to exercise due diligence in respect of, harmful activities by non-state actors, notably in the human rights and environmental field. ${ }^{14}$ These different routes, however, may prove inconclusive as the conditions for the attribution of the conduct of non-state actors to states are rather strict, and the conditions for the application of the obligations of states to exercise due diligence in relation to non-state actors may not be met. The same holds true for the mechanism of attribution of responsibility.

Therefore, it will often be difficult — or outright impossible — to capture situations involving non-state actor misconduct through the traditional channels of state responsibility. It is traditionally found that a relaxation of the standards of attribution of conduct may dangerously conflate the distinction between the public and private sphere, and bring about an unwarranted expansion of the scope of

\footnotetext{
12 Nollkaemper and Plakokefalos (2014), p. 341.

13 Articles on Responsibility of States for Internationally Wrongful Acts, ILC Yearbook 2001/II(2) (ARSIWA).

${ }^{14}$ See in the human rights field, e.g., Osman v. the United Kingdom, App. No. 23452/94 (ECtHR, 28 October 1998) Reports 1998-VIII, paras. 115-116. See also Ilaşcu and others v. Moldova and Russia, App. No. 48787/99 (ECtHR, 8 July 2004) Reports 2004-VII, [GC], paras. 330-331; Application of the Convention on the Prevention and Punishment of the Crime of Genocide (Bosnia and Herzegovina $v$. Serbia and Montenegro), Judgment, ICJ Reports 2007, p. 43, para. 430 (Bosnian Genocide); 'Guiding Principles on Business and Human Rights: Implementing the United Nations "Protect, Respect and Remedy" Framework', Principle 1. In the field of environmental law see Pulp Mills on the River Uruguay (Argentina v. Uruguay), Judgment, ICJ Reports 2010, 14, para.193; Responsibilities and Obligations of States Sponsoring Persons and Entities with Respect to Activities in the Area, Advisory Opinion, Seabed Disputes Chamber of the International Tribunal for the Law of the Sea, Case No 17, 1 February 2011, (2011) 50 ILM 458, paras.110, 117-20.
} 
responsibility. ${ }^{15}$ That said, such resistance is sometimes contested. Indeed, from an accountability perspective, strict standards, e.g., the requirement of 'effective control' of a state over a non-state actor's conduct, may give rise to accountability gaps in case non-state actors operate at sufficient arm's length from states, even when being factually engaged in joint enterprises with them. ${ }^{16}$ Such accountability gaps may similarly be witnessed in case states (such as failed states) do not have the capacity to influence non-state actor activity and thus are not in a position to take protective measures. ${ }^{17}$ Such gaps may notably manifest themselves where states do not control the territory on which the non-state actors are active, or when states have no economic links with the non-state actors that offer them leverage to steer their conduct into a desirable direction. It is this accountability agenda that invites international lawyers to reflect upon the possibility of a more autonomous framework to hold non-state actors responsible for their own action, and to relate such responsibility to the responsibility of states and other actors. The various contributions to this symposium all share such an accountability agenda. They are, to a greater or lesser extent, articulated around the search for an improvement of regulation and accountability mechanisms with respect to the potential harmful actions of non-state actors, especially when these have been acting in conjunction with states.

Difficulties faced by policy-makers and international lawyers as to holding nonstate actors responsible, possibly together with states, are not only of a substantive nature. There are also strong procedural obstacles in holding those actors responsible, stemming from the limited jurisdictional remit of international and national dispute-settlement mechanisms. As a result of these limitations, combined with the above-mentioned uncertainty as to the international obligations of non-state actors, there is limited practice as far as shared responsibility between non-state actors and other actors is concerned. Only some occasional instances of disputesettlement mechanisms addressing the question of shared responsibility between non-state actors and states can be gleaned. One such rather exceptional situation is litigation in United States federal courts under the Alien Tort Statute, ${ }^{18}$ which private plaintiffs have relied on to bring cases against multinational corporations for violations of international law, typically alleging the latter's complicity in internationally wrongful acts committed by states. In some cases it was implied that non-state actors and states could share responsibility on the basis of the former aiding and assisting the latter in committing internationally wrongful acts. ${ }^{19}$ Ultimately, however, these cases have had little relevance for the question of shared

\footnotetext{
${ }^{15}$ Compare Bosnian Genocide, para. 406 (ruling, with respect to Art. 8 ARSIWA, that "the "overall control" test is unsuitable, for it stretches too far, almost to breaking point, the connection which must exist between the conduct of a State's organs and its international responsibility').

16 See the contribution of Trapp (2015), Section 3.1, where she advocates a relaxation of the effective control standard when it comes to attributing conduct of terrorist groups to states.

17 See the contribution of Trapp (2015), Section 3.2.

18 Alien Tort Statute, 28 USC $§ 1350$.

19 Kiobel v. Royal Dutch Petroleum Co. 133 S.Ct. 1659 (2013) (Kiobel) is, again, a good example, where the plaintiffs suggested that the corporation in question had aided and abetted Nigeria in violating human rights, see Karavias (2015), Section 4.
} 
responsibility under international law. Apart from the fact that many of these cases have ended in a settlement between the plaintiffs and the corporations, for immunity reasons the state was not a party to the proceedings, thus obviating the need for US judges to examine issues of shared responsibility. Moreover, some US courts doubted whether corporations had international obligations in the first place, thus foreclosing the path towards responsibility. ${ }^{20}$

Situations of shared responsibility involving non-state actors may exceptionally arise, however, pursuant to specific institutional regimes, notably where states have empowered non-state actors to carry out certain activities. The field of economic activities carried out on the international seabed or 'Area' is a case in point. Under the United Nations (UN) Convention on the Law of the Sea (LOSC), ${ }^{21}$ corporations can enter into an international contract for the exploration of polymetallic nodules, and accordingly incur obligations and responsibility under international law. In its 2011 Advisory Opinion, the Seabed Chamber of the International Tribunal of the Law of the Sea appeared to acknowledge the possibility of multiple actors sharing responsibility under the LOSC, where it held that '[j] oint and several liability arises where different entities have contributed to the same damage so that full reparation can be claimed from all or any of them. ${ }^{22}$ While the Chamber may only have referred to responsibility shared between states and international organisations, it is arguable that also corporations, on the basis of the contract, may share responsibility for wrongful acts in breach of the contract. However, even if this were the case, this shared responsibility does not exist as a matter of general international law, but follows the existence of the contractual obligations. ${ }^{23}$

All in all, the specific instances where questions of the responsibility of non-state actors, as well as of its shared responsibility with states, have been raised in adjudication remain rather limited or inconclusive. This is why it has not been possible to draw from existing practice any general conclusions as to the shared responsibility of non-state actors. It is the aim of this symposium to go beyond the

\footnotetext{
${ }^{20}$ See, e.g., Kiobel v. Royal Dutch Petroleum Co., 621 F.3d 111 (2nd Cir. 2010); Doe v. Nestle, 748 F. Supp. 2d 1057 (C.D. Cal. 2010). The chances of US courts examining issues of shared responsibility between organised non-state actors and states has been even further diminished after the US Supreme Court's decision in Kiobel, which severely circumscribed the jurisdictional ambit of the Alien Tort Statute by, relying on the presumption against extraterritoriality, barring relief for violations of the law of nations occurring outside the United States under the Alien Tort Statute, requiring instead a strong connection of the case to the US. See Kiobel ibid.

21 United Nations Convention on the Law of the Sea, Montego Bay, 10 December 1982, in force 16 November 1994, 1833 UNTS 3 (LOSC).

22 Responsibilities and Obligations of States Sponsoring Persons and Entities with Respect to Activities in the Area, para. 201. Note that natural and juridical persons are eligible to carry out activities in the Area, in accordance with Art. 153(2) LOSC, provided that they be either nationals of a state party or effectively controlled by its nationals, and are sponsored by such state. When damage arises out of a wrongful act in the conduct of the operations of such a contractor, as a result of its activity, its responsibility or liability will be engaged in accordance with Art. 22 of the LOSC Annex III.

23 See the contribution by Karavias (2015), Section 3.2 on shared responsibility between a multinational enterprise and the host state. MacLeod argues that the contractual relationship between the home and host states and the private security corporation might be the only legal ground that can lead to the responsibility of the latter, albeit in a domestic law setting, without, however, reflecting the shared nature of the enterprise undertaken, see MacLeod (2015), Section 2.
} 
particular situations that have arisen in dispute-settlement. More specifically, the contributors have been asked to identify new patterns in both recent practice and literature of non-state actors being held co-responsible for their contributions to harmful outcomes, as well as to reflect critically on the added value of a shared responsibility approach when it comes to regulating the activities of non-state actors.

\section{Cross-Cutting and Recurring Legal Questions}

The question of sharing responsibility for harmful acts involving non-state actors and states that is at the heart of this symposium is obviously wide and raises different types of legal issues. Therefore, this question will be broken down into three sub-issues, which will be addressed in what follows. These issues are addressed in the contributions to this symposium, although these contributions do not necessarily adopt the same structure. The three sub-questions pertain to the relevance of shared responsibility stricto sensu, in the sense of responsibility for internationally wrongful acts (Sect. 5.1); the possibility to litigate issues of shared non-state actor responsibility in the courts, whether international or domestic ones (Sect. 5.2); and the question of whether the classic responsibility régime is suited to capture the specific challenges of non-state actors, or whether, instead, responsibility, at least in the strict sense, should be abandoned in favour of an alternative and more realistic approach that emphasises standard-setting (or 'regulation') and accountability via supervisory mechanisms (Sect. 5.3).

\subsection{Non-State Actor Responsibility for Internationally Wrongful Acts}

A key question is whether it is a useful heuristic device to examine the question of responsibility of non-state actors-alone or shared with states-from the angle of the traditional concepts and principles of responsibility. The practice in relation to wrongful acts and/or harmful outcomes caused by non-state actors, as detailed in the remainder of the symposium, provides little support for a transposition of the concepts and principles of international responsibility to non-state actors. This obviously already follows from the fact that, with the exception of armed opposition groups, there are few obligations that directly bind non-state actors. ${ }^{24}$ Even

\footnotetext{
${ }^{24}$ Armed groups, however, are bound by international humanitarian law, in particular Common Art. 3 of the Geneva Conventions 1949 (Geneva Convention for the Amelioration of the Condition of the Wounded and Sick in Armed Forces in the Field, 75 UNTS 31; Geneva Convention for the Amelioration of the Condition of the Wounded, Sick and Shipwrecked Members of Armed Forces at Sea, 75 UNTS 85; Geneva Convention relative to the Treatment of Prisoners of War, 75 UNTS 135; Geneva Convention relative to the Protection of Civilian Persons in Time of War, 75 UNTS 287), and Art. 1(1) Protocol Additional to the Geneva Conventions of 12 August 1949, and relating to the Protection of Victims of Non-International Armed Conflicts (Protocol II), Geneva, 8 June 1977, in force 7 December 1979, 1125 UNTS 609; see also the contribution by Bílková (2015), Section 2.2. Terrorist groups for their part are bound by a series of terrorism suppression conventions; see also the contribution by Trapp (2015), Section 2. It is generally considered that corporations are not bound by international (human rights) law; see Karavias (2015), Sections 5.2 and 5.3. Private security corporations are also not bound by international law, see McLeod 2015, Section 2.
} 
assuming that non-state actors could be duty-bearers under international law whose responsibility can be envisaged, a number of further questions arise.

One such question concerns the possibility of the transposition of rules of state responsibility by analogy. This is not an easy operation and it would require some serious fine-tuning of the ARSIWA if they were to be successfully applied, notably in relation to principles of attribution. ${ }^{25}$

A related question is whether responsibility for wrongful conduct involving nonstate actors is to be assessed on the basis of independent acts of these actors, or rather on the basis of a shared contribution to a single harmful outcome, with the actors' acts being dependent on each other for the outcome to materialise. In many situations, nonstate actors and states may separately contribute to, or aggravate, a single harmful outcome. For instance, states may provide support to non-state actors, or non-state actors may provide support to (aid/assist) states, in violation of international law, with the supported actor then committing an internationally wrongful act (e.g., a violation of international humanitarian law or human rights law, or a terrorist act) or causing harm otherwise. ${ }^{26}$ Such separate action may also occur when states fail to take sufficient measures to prevent harmful activity by non-state actors, e.g., when they condone the presence of terrorists on their territory. ${ }^{27}$ Another example arises when states fail to call non-state actors to account for wrongful acts committed or injuries caused (e.g., by not living up to their duty to prosecute or extradite). ${ }^{28}$ In those situations, the responsibility of non-state actors and states may be engaged on the basis of discrete conduct. This is in line with some of the classic paradigms of the law of international responsibility, which tend to isolate acts of different actors with a view to holding them to account independently of each other. ${ }^{29}$

In other situations, it may be appropriate to adopt a perspective of joint action, in which the various actors' contributions may not be isolated from each other. One can think here of an armed opposition group mounting a joint military operation together with a state against another state in violation of the principle of nonintervention, and/or causing civilian casualties in violation of the rules of

\footnotetext{
25 See notably Bílková (2015), Section 2.

26 See in this respect ICJ, Military and Paramilitary Activities in and against Nicaragua (Nicaragua $v$. United States of America), Merits, ICJ Reports 1986, 14, addressing the support which the United States provided to non-state armed groups in Nicaragua at para. 116: '[The Court] takes the view that the contras remain responsible for their acts, and that the United States is not responsible for the acts of the contras, but for its own conduct vis-à-vis Nicaragua, including conduct related to the acts of the contras. What the Court has to investigate is not the complaints relating to alleged violations of humanitarian law by the contras, regarded by Nicaragua as imputable to the United States, but rather unlawful acts for which the United States may be responsible directly in connection with the activities of the contras' (emphasis in the original). See further on the inferences for shared responsibility that could be drawn from Nicaragua, as well as from the ICJ judgment in Bosnian Genocide for that matter: Bílková, Section 2.2. See on shared responsibility arising as a result of corporations aiding and assisting states in committing violations of international law: Karavias (2015), Sections 3.2, 4 and 5.

27 See however Trapp (2015), Section 3.2.1, arguing that '[s]uch states lack the general capacity, resources or territorial control that is a factual pre-requisite for effective counter-terrorism measures', and instead suggesting in Section 3.2.2 a 'sphere of influence' approach to prevention.

28 See Trapp (2015), Section 3.3, in respect of terrorism.

29 Such a principle was affirmed and discussed by Roberto Ago in his third report on state responsibility, see UN Doc. A/CN.4/246, Add.1-3 (1971). See generally Nollkaemper and Jacobs (2013).
} 
international humanitarian law. ${ }^{30}$ In this situation, there may be a single conduct committed by multiple actors, resulting in a single injury. It could be submitted that this conduct should technically be attributed to more than one actor (i.e., double or multiple attribution), although such multiple attribution is rather rare in international law, also in the state responsibility context. ${ }^{31}$ Leaving aside that option, the question is whether it is conceptually helpful to consider such situations in terms of joint responsibility, and what the implications of such responsibility would be, e.g., with respect to the obligation to provide reparation.

\subsection{Dispute-settlement}

One must admit that in respect of non-state actors, discussions of shared responsibility, and the consequences attached to it, are at first sight somewhat theoretical, given the absence of international dispute-settlement mechanisms with jurisdiction over non-state actors. ${ }^{32}$ As revamping the international judicial system is not a realistic option, a more insightful avenue is to consider how existing disputesettlement mechanisms could be creatively used to determine questions, and consequences, of shared responsibility involving non-state actors and other actors. Such mechanisms are mainly found at the domestic level, as some non-state actors have (domestic) legal personality, including the capacity to sue and be sued. Domestic courts can then hold non-state actors responsible under international law, or under (transnational) domestic law, for acts which they carried out together with other actors, such as states. These courts may lack jurisdiction over the latter, however, for instance because of applicable immunities. In a situation of apparent shared responsibility, it may be necessary to consider domestic courts in connection with dispute-settlement or compliance-monitoring mechanisms which may have jurisdiction over the other actor(s) sharing responsibility with the non-state actor. By way of example, domestic courts hearing cases against corporations that have assisted states in the commission of wrongful acts may consider and perhaps even develop

\footnotetext{
30 See Bílková (2015), Section 1.

31 See however State of the Netherlands v. Mustafić et al., ECLI:NL:HR:2013:BZ9228 (6 September 2013); State of the Netherlands v. Hasan Nuhanović, ECLI:NL:HR:2013:BZ9225 (6 September 2013). The Court opined in this respect that Art. 48 of the Articles on the Responsibility of International Organizations, ILC Report on the work of its sixty-third session, UNGAOR 66th Sess., Supp. No. 10, UN Doc. A/66/10 (2011) (ARIO)—which enshrines the principle that '[w]here an international organization and one or more States or other international organizations are responsible for the same internationally wrongful act, the responsibility of each State or organization may be invoked in relation to that act''expressly leaves open the possibility ... of dual attribution to the international organization and the State concerned' and thus to 'more than one State or organization being held responsible for the consequences of an internationally wrongful act' (para. 3.9.4). Contra: Nollkaemper PA, Jacobs D, Shared Responsibility in International Law: A Conceptual Framework, SHARES Research Paper 03 (2011), ACIL 2011-07 (revised version, May 2012), available at http://www.sharesproject.nl/wp-content/ uploads/2012/05/SHARES-RP-03-final.pdf, p. 111-(arguing that an international organisation and a state can both be held responsible for the same wrongful act, but not on the basis of this act being attributed to both of them, but rather on the basis of 'parallel attribution based on independent acts'); Advocate General's advisory opinion in the same cases, ECLI:NL:PHR:2013:BZ9228 (3 May 2013); ECLI:NL:PHR:2013:BZ9225 (3 May 2013), para. 5.14. See also Messineo (2014), p. 60.

32 That is with the exception of the Deep Seabed Chamber of the LOSC, see Plakokefalos (2013).
} 
cooperative arrangements with international human rights supervisory bodies that have jurisdiction over the state which was assisted by the corporation (such a body could, e.g., open a proprio motu investigation into the state's conduct). ${ }^{33}$

Alternatively, domestic court proceedings which result in a finding of the responsibility of a non-state actor, e.g., of a terrorist actor, may contain a wealth of information laying blame at the doorstep of another actor, e.g., a state supporting terrorism. ${ }^{34}$ Such information may be used in successive litigation against the latter in another forum. At any rate, at a diplomatic level it can provide evidence as to the international responsibility of the state, which the latter-given the esteem in which court decisions are typically held-cannot easily dismiss. Therefore, domestic courts may want to avoid offering a truncated narrative in cases of apparent joint responsibility. While they may have jurisdiction over only one actor involved, they may want to anticipate that their findings can be used in other fora, and thus they may, tentatively, identify the grounds on which the various actors may share responsibility, as well as the extent to which they respectively contributed to the eventual harm. Such a finding may not be binding on the mechanism hearing a subsequent responsibility case against another actor involved, but at least it can provide an authoritative point of reference.

\subsection{The Turn to Standard-Setting and Accountability as an Alternative to Responsibility}

Analyses of shared responsibility in respect of non-state actors may not be limited to merely operationalising shared responsibility for specific legal subjects. Instead, they may unearth more fundamental questions as to the nature and limitations of international responsibility. The difficulty of determining the responsibility of nonstate actors has, both in practice and in scholarship, led to a quest for alternatives. Thinking out of the box may be even more relevant and insightful in respect of nonstate actors, since there are reasons for construing the nature of the latter as fundamentally different from the states and international organisations for which the international responsibility régime was originally devised. Non-state actors are 'organisations' that are not necessarily pursuing the public good. Furthermore, they are incorporated under domestic law (e.g., corporations, including private security corporations and non-governmental organisations), or not incorporated at all (e.g., armed groups). Often, they entertain non-horizontal relationships with other international legal subjects (states and international organisations), due to de facto power differences and the absence of recognised legal personality. ${ }^{35}$ Combined with the difficulty to directly bind non-state actors under international law, the question therefore arises whether the international legal responsibility régime as we know it is well-suited to apply to them.

\footnotetext{
33 See notably Karavias (2015), Section 4 (arguing that domestic courts should take into consideration findings of breach by human rights courts or treaty bodies).

34 See Trapp (2015), Section 2 in fine.

35 Note, however, that some non-state actors may rival states in terms of economic or military clout, e.g., major multinational corporations, or well-organised armed opposition groups.
} 
It is against this backdrop that contributors to this symposium issue have been invited to reflect on possible alternative regimes for (shared) responsibility involving specific non-state actors. Almost all authors have considered abandoning the dogmatic focus on responsibility for internationally wrongful acts as a means to regulate joint action involving organised non-state actors. Thereby, they recognise that in light of the difficulties to reform (or transpose) the existing law of international responsibility, a more promising - and probably realistic-route to take may be to embrace a broader accountability approach.

One such alternative, that nonetheless stays close to another paradigm of international law, is suggested in the contribution of Veronika Bílková. She considers the application of a liability approach that could offer remedies to victims for injurious non-state action that falls short of a violation of an international obligation. ${ }^{36}$ The liability approach, however, is beset by similar problems as the responsibility approach: it remains elusive how precisely to conceive of joint liability, and how to address the temporary nature of some non-state actors.

More promising seems to be the standard-setting (or regulatory) approach, with advocates strengthening standards and commitments by both non-state actors and states, coupled with supervisory mechanisms. Such standards could be unilaterally adopted by a non-state actor or jointly developed and overseen by non-state actors and other actors, and are aimed at preventing harm from occurring and making nonstate actors accountable. They are not necessarily legally binding. This is a route that is already being taken with respect to the activities of multinational corporations, private security companies, and armed groups, as is illustrated by the contributions of Markos Karavias, Sorcha MacLeod, and Veronika Bílková.

It is important to stress here that such perspectives are not necessarily meant to be a substitute for a responsibility regime. After all, the substitution of an ex post regime of responsibility for breach of ex ante assumed legally binding obligations by a regime that relies on the ex ante assumption of non-binding, non-legal obligations, seems difficult to justify. The point made here is different: if there are no primary obligations to begin with, a regime of responsibility simply cannot apply. Moreover, even where primary obligations exist, it would be difficult to see how the ARSIWA can be transposed so as to accommodate the peculiarities arising out of the nature of non-state actors (i.e., their lack of hierarchical organisation, and their temporary existence). Therefore, what is suggested is an ex ante regime of prevention that seeks to regulate the conduct of non-state actors without imposing binding international obligations on them. This regime differs from the one envisaged in the ARSIWA, as it provides yardsticks for the monitoring of non-state actors' compliance with non-binding obligations they have assumed.

Standard-setting is not apposite to every non-state actor, however. For instance, as Kimberley Trapp argues in her contribution, as terrorists deliberately defy the international legal order, they have no interest whatsoever in self-regulation. ${ }^{37}$ At

\footnotetext{
36 Bílková (2015), Section 3.1.

37 Trapp (2015), Section 1.
} 
the same time, states that may be involved in harbouring, aiding and assisting, or directly participating in terrorist operations are already bound by primary obligations. The challenge is to ensure that states assume their responsibility to comply with the obligations which they have set for themselves, and to ensure that the existing law is applied expansively, so that states do not get away with supporting or condoning terrorism. ${ }^{38}$ In contrast, a turn to standard-setting is clearly discernible with respect to the activities of transnational corporations, armed groups and private security companies.

Standard-setting and supervisory mechanisms perform two distinct functions. Standard-setting aims at imposing a normative framework on non-state actors that moves away from the context of, strictly speaking, binding obligations. Supervision (or 'compliance-monitoring') allows for determinations of accountability, short of responsibility. Within this latter concept, various forms may be distinguished. Supervision can refer to monitoring the compliance of actors with binding obligations. This voluntary move away from the classic responsibility régime does not imply, however, that non-compliance cannot at the same time be a breach of an international obligation leading to international responsibility proper. Compliancemonitoring can also function as a non-legally binding test of the performance of the actor in question against the observance of a given target (apart from legally binding obligations). ${ }^{39}$ It is useful to keep the two concepts apart.

A host of standard-setting and compliance-monitoring initiatives relevant to nonstate actors are in the process of being developed. ${ }^{40}$ These initiatives often involve multiple stakeholders, including non-state actors, states, and international organisations, in acknowledgement of the fact that multiple actors can cause harm, either through direct commission or a failure to act. Interestingly, the term 'shared responsibility' has been used in this context, not to denote shared responsibility for internationally wrongful acts, but rather to denote a—not necessarily legal—shared duty to put in place due diligence-based mechanisms to prevent violations, and to provide for grievance mechanisms in case of violations. Due diligence in this context does not denote the classic notion that speaks to the nature of the primary obligation. It is used as a convenient notion of a general-again not necessarily legal-duty of vigilance or care. In particular, the UN Special Representative for Transnational Corporations and Human Rights, John Ruggie, recognised 'that some business and human rights challenges require multi-stakeholder responses, [by allocating] shared responsibilities ... within complex collaborative networks that can include any combination of host and home states, corporations, civil society

\footnotetext{
38 Thus, Trapp suggests using the 'overall control' standard for attribution of terrorist conduct to states under Art. 8 ARSIWA, as well as a 'sphere of influence' responsibility concept inspired by the ICJ's judgment in the Bosnian Genocide case. Also, she recommends a strict construction of aut dedere aut judicare obligations in anti-terrorism conventions to prevent states from getting away with not prosecuting or extraditing presumed terrorists (Trapp 2015).

39 See Shelton (2003).

40 See notably: Marx et al. (2012); Peters et al. (2009). For a detailed account of standard-setting and the prospects of its internalisation by the private security corporations, see MacLeod (2015), Sections 3 and 4.1 .
} 
actors, industry associations, international institutions and investors groups' ${ }^{41}$ This conceptualisation of shared responsibility echoes the discussion regarding various (international) actors' responsibility to protect vulnerable populations from core international crimes. $^{42}$

The emphasis of this shared responsibility concept does not so much lie on the ex post facto undoing or repairing of consequences of internationally wrongful acts (although this may be part of it), but rather on the a priori joint establishment of acceptable standards of conduct, and an assessment of the conduct of non-state actors, whether or not in conjunction with states, against such standards. For instance, corporations, via hybrid multi-stakeholder initiatives or transnational private regulation - and often in cooperation with, or supported by states-develop standards and set up accountability mechanisms to protect global public goods that may be affected by corporate activity. ${ }^{43}$ Armed groups, in cooperation with, or at the behest of, non-governmental organisations ${ }^{44}$ or international organisations, ${ }^{45}$ commit themselves to upholding international humanitarian law and human rights law through 'deeds of commitment' or peace treaties, ${ }^{46}$ and are, at least in part, subject to international supervisory processes. ${ }^{47}$

It is of note that the commitments by various actors and categories are not communicating vessels: the responsibility assumed by one actor does not diminish the responsibility assumed by another. Being of a different nature and independent of each other, these responsibilities should be seen as complementary and mutually reinforcing. The Commentary to the Guiding Principles on Business and Human Rights indeed suggests with respect to the allocation of responsibilities between corporations and states: 'The [corporate] responsibility to respect human rights is a global standard of expected conduct for all business enterprises wherever they operate. It exists independently of States' abilities and/or willingness to fulfill their own human rights obligations, and does not diminish those obligations. ${ }^{48}$ This principle ensures that one actor does not shift the burden or the blame to another actor.

\footnotetext{
${ }^{41}$ Cf. Ruggie J., 'Business and Human Rights: Mapping International Standards of Responsibility and Accountability for Corporate Acts', UN Doc. A/HRC/4/035 (9 February 2007), para. 53, see also paras. 52-62; Ruggie J., Report of the Special Representative of the Secretary-General on the issue of human rights and transnational corporations and other business enterprises, Addendum, 'Summary of five multistakeholder consultations', UN Doc. A/HRC/8/5/Add.1 (23 April 2008), see section VI (Improving the human rights performance of business through multi-stakeholder initiatives).

42 See for the multitude of (international) institutions' role in this respect: Zyberi (2013); Hoffmann et al. (2012).

43 See Cafaggi (2012).

44 See notably the Swiss non-governmental organisation Geneva Call, a "neutral and impartial nongovernmental organization dedicated to promoting respect by armed non-State actors (ANSAs) for international humanitarian norms in armed conflict', see http://www.genevacall.org/who-we-are/.

45 See, e.g., Principles and Guidelines on Children Associated with Armed Forces or Armed Groups (Paris Principles), UN Children's Fund (UNICEF), February 2007.

46 See on standard-setting: Roberts \& Sivakumaran (2012).

47 See on enhancing and enforcing compliance: Ryngaert and Vande Meulebroucke (2011).

48 'Guiding Principles on Business and Human Rights: Implementing the United Nations "Protect, Respect and Remedy" Framework', Commentary to Principle 11.
} 
A major challenge facing these multi-stakeholders' standard-setting and supervisory initiatives pertains to participation and, more broadly, legitimacy: they are legitimised on the basis of shared responsibility and are self-policed. ${ }^{49}$ In response to demands for a better participation of (public interest) stakeholders, states and international organisations may want to assume their 'shared' responsibility-which is derived, as far as human rights are concerned, from their 'duty to protect'-by facilitating and orchestrating non-state actor standardsetting and compliance-monitoring. ${ }^{50}$ In some situations and in relation to some non-state actors, they can do so by means of market-based mechanisms, e.g., public procurement, financial reporting, and trade measures, ${ }^{51}$ or by more forceful measures such as sanctions. ${ }^{52}$

\section{The Structure of This Symposium}

Structure is always a matter of choice. The editors have assumed that different types of non-state actors do not necessarily yield the application of a similar regime of responsibility. Therefore, this symposium is articulated around the four main organised non-state actors. Questions of shared responsibility will be successively examined in connection with armed groups (Veronika Bílková); multinational corporations (Markos Karavias); private security corporations (Sorcha MacLeod); and terrorist groups (Kimberley Trapp). By virtue of this actor-based classification, the contributions demonstrate that the question of shared responsibility between non-state actors and states differs from one type of organised non-state actor to the other, but may also vary in accordance with the type of their interaction with states.

Although their individual structure varies, the four contributions to this symposium all consider, both empirically and theoretically, each of the three above-mentioned sub-questions: the relevance of responsibility in the traditional sense of the term, dispute-settlement, and (apart from the contribution on non-state terrorist actors by Kimberly Trapp) the turn to standard-setting as an alternative to responsibility. In the contribution of Sorcha MacLeod on private security corporations, the turn to standard-setting occupies a central place. ${ }^{53}$

\footnotetext{
49 See on the necessity of engaging organised non-state actors regarding shared responsibility issues: Ruggie (2004).

50 See Abbott and Snidal (2009).

51 See on how these market-based mechanisms have been and can be resorted to: Ryngaert (2015).

52 A fine example of such a sanctions regime is offered by the UN Security Council's practice of imposing sanctions on persons who are presumed to support terrorists, on armed groups active in the Democratic Republic of the Congo, Liberia and Darfur (notably the Al Qaeda and Taliban sanctions on the basis of UN Doc. S/RES/1267 (1999)), and on persons who violate the rights of the child in armed conflicts, see UN Doc. S/RES/1493 (2003); UN Doc. S/RES/1521 (2003); UN Doc. S/RES/1552 (2004); UN Doc S/RES/1556 (2004); and UN Doc. S/RES/1596 (2005). Note that on closer inspection, the relevant resolutions oblige states to enforce these sanctions; they may not impose direct obligations on the armed groups themselves. From the perspective of the targeted person, these sanctions are domestic rather than international, and their legality may be challenged on the basis of domestic law.

53 MacLeod (2015), Section 3.
} 


\section{Lessons Learnt and the Way Forward}

From the four contributions, different types of interactions between non-state actors and states could be gleaned, as well as, corresponding to this, different ways in which non-state actors and states, either jointly or independently, contribute to the same harm. Non-state actors may team up with states to bring about a prohibited or harmful outcome, either by taking joint action, or by one actor aiding and assisting the other. An example of the former is a military operation conducted jointly by state forces and a private military company, resulting in violations of humanitarian law; an example of the latter is a multinational corporation giving logistical support to a repressive state. Short of teaming up with each other, states and non-state actors may also take concurrent yet uncoordinated action contributing to the same harm. This may occur where a state or international organisation passively stands by when an armed group commits atrocities or launches terrorist attacks, or where a state fails to prosecute or extradite presumed terrorists present on its territory. In all these cases, shared (joint/concurrent/cumulative) responsibility for international law violations could potentially ensue.

Such a shared responsibility regime involving non-state actors and states could theoretically be based on the somewhat more mature shared responsibility regime implicit in the ARSIWA and further developed by scholars of state responsibility. The contributors to this symposium have seen some potential in this transposition, and have notably drawn attention to the application of the regimes of attribution of conduct and attribution of responsibility (the latter denoting aiding and assisting, direction and control, and coercion) to the interaction between non-state actors and states. ${ }^{54}$ Ultimately, however, most of them have proved to be somewhat sceptical of the prospects of transposing the state responsibility regime to non-state actors, on a number of grounds. They have pointed out that an international responsibility regime can only work adequately if its addressees are bound by primary norms of international law in the first place ${ }^{55}$; in respect of non-state actors, which largely lack international legal personality, or at least legal capacity, this may indeed be an insurmountable challenge. The authors have signalled the dearth of disputesettlement mechanisms competent to establish shared responsibility between nonstate actors and states - while nevertheless highlighting potential synergies between various mechanisms. ${ }^{56}$ And they have drawn attention to the incommensurability of non-state actors and states; the peculiar nature of the former-loosely organised, temporary, diverse, illegitimate, or even outright criminal-may arguably render a responsibility paradigm for non-state-state interactions inappropriate. ${ }^{57}$

\footnotetext{
54 See Bílková (2015), Sections 2.1 and 2.2; Karavias (2015), Section 3.2; Trapp (2015), Sections 2 and 3.1. This is not the case in MacLeod (2015), see Section 1.

55 See notably Bílková (2015) and Karavias (2015).

56 Trapp (2015), Section 2 in fine; Karavias (2015), Section 4.

57 Bílková (2015), Section 2 in fine; MacLeod (2015), Sections 1, 2. The peculiar character of terrorist groups has led Trapp even to focus her contribution on the shared responsibility of states and individual terrorists rather than of terrorist groups. See for her justification see footnote 9 of her contribution (Trapp 2015).
} 
Given the limitations of a formal responsibility regime, three of the four authors have explored, and ultimately favoured, albeit cautiously, the standard-setting approach to shared responsibility, the traits of which have been set out at length earlier in this contribution. Such an approach has undeniable benefits, as it ensures ex ante commitments to standards 'owned' by the various actors involved, via codes of conduct or unilateral declarations. But its constraints are undeniable as well. As a commitment to these standards, and openness to compliance-monitoring, are in essence voluntary, ${ }^{58}$ there is no guarantee that non-state actors and states will embrace them, or comply with them. Given these limitations, an ex post formal responsibility approach may suddenly look more attractive.

At the end of the day, the choice faced by international lawyers confronted with questions of accountability for the conduct of non-state actors in conjunction with states remains the very same choice between two opposite conceptual options. On the one hand, one can choose to transpose to such questions the mainstream categories inherited from a time when both international law and the world looked (and were looked at) different(ly). On the other hand, one can decide to emancipate oneself from these categories-be it responsibility, wrongfulness, attribution or even legal personality - and change the paradigm from which such contemporary issues must be addressed. Should one choose for the latter option, and its reformist ambition, one should do so with the awareness that international law is always reformed from within unless one decides to address questions of the shared responsibility of non-state actors from the vantage point of another discipline. It cannot be excluded, as some of the following contributions show, that such a move away from international law itself may sometimes be the only possible route. Yet, as all the following contributions-directly or indirectly-demonstrate, it seems that international lawyers will continue to embrace both approaches, which, to some extent, can be envisaged simultaneously without contradicting one another. ${ }^{59}$

Open Access This article is distributed under the terms of the Creative Commons Attribution 4.0 International License (http://creativecommons.org/licenses/by/4.0/), which permits unrestricted use, distribution, and reproduction in any medium, provided you give appropriate credit to the original author(s) and the source, provide a link to the Creative Commons license, and indicate if changes were made.

\section{References}

Abbott KW, Snidal D (2009) Strengthening international regulation through transnational new governance: overcoming the orchestration deficit. Vanderbilt J Transnatl Law 42:501-578

Bílková V (2015) Armed opposition groups and shared responsibility. Neth Int Law Rev. doi:10.1007/ s40802-015-0014-1

Cafaggi F (2012) Transnational private regulation and the production of global public goods and private 'bads'. EJIL 23:695-718

Gal-Or N, Ryngaert C, Noortmann M (2015) (eds) Responsibilities of the non-state actor in armed conflict and the marketplace: theoretical considerations and empirical findings. Brill, The Hague

Hoffmann J, Nollkaemper PA, Swerissen I (2012) (eds) Responsibility to protect: from principle to practice. Amsterdam University Press, Amsterdam

58 Bílková (2015), Section 3, in fine.

59 On this point, see especially the remarks of Karavias (2015), Section 6, in fine. 
Karavias M (2015) Shared responsibility and multinational enterprises. Neth Int Law Rev. doi:10.1007/ s40802-015-0008-z

MacLeod S (2015) Private security companies and shared responsibility: the turn to multistakeholder standard-setting and monitoring through self-regulation-'plus'. Neth Int Law Rev. doi:10.1007/ s40802-015-0017-y

Marx A, Maertens M, Swinnen J, Wouters J (2012) (eds) Private standards and global governance: economic, legal and political perspectives. Edward Elgar, Cheltenham

Messineo F (2014) Attribution of conduct. In: Nollkaemper PA, Plakokefalos I (eds) Principles of shared responsibility in international law: an appraisal of the state of the art. Cambridge University Press, Cambridge, pp 60-97

Nollkaemper PA, Jacobs D (2013) Shared responsibility in international law: a conceptual framework. Mich J Int Law 34:359-438

Nollkaemper PA, Plakokefalos I (2014) Conclusions: beyond the ILC legacy. In: Nollkaemper PA, Plakokefalos I (eds) Principles of shared responsibility in international law: an appraisal of the state of the art. Cambridge University Press, Cambridge, pp 341-363

Peters A et al (2009) (eds) Non-state actors as standard-setters. Cambridge University Press, Cambridge

Plakokefalos I (2013) Shared responsibility aspects of the dispute settlement procedures in the Law of the Sea Convention. J Int Disput Settl 4:385-405

Roberts A, Sivakumaran S (2012) Lawmaking by non-state actors: engaging armed groups in the creation of international humanitarian law. Yale J Int Law 37:107-152

Ruggie J (2004) Reconstituting the global public domain: issues, actors and practices. Eur J Int Relat $10: 499-531$

Ryngaert C (2015) Transnational private regulation and human rights: the limitations of stateless law and the re-entry of the state. In: Letnar Cernic J, Van Ho T (eds) Direct human rights obligations of multinational corporations. Wolf Legal Publishers, Nijmegen (forthcoming)

Ryngaert C, Vande Meulebroucke A (2011) Enhancing and enforcing compliance with international humanitarian law by non-state armed groups: an inquiry into some mechanisms. J Confl Secur Law $16: 443-472$

Shelton D (2003) (ed) Commitment and compliance: the role of non-binding norms in the international legal system. Cambridge University Press, Cambridge

Trapp KN (2015) Shared responsibility and non-state terrorist actors. Neth Int Law Rev. doi:10.1007/ s40802-015-0018-X

Zyberi G (2013) (ed) An institutional approach to the responsibility to protect. Cambridge University Press, Cambridge

Jean d'Aspremont is Professor of Public International Law at the University of Manchester, and is Professor of International Legal Theory at the University of Amsterdam.

André Nollkaemper is Professor of Public International Law at the Faculty of Law of the University of Amsterdam, and director of the research project on Shared Responsibility in International Law (SHARES).

Ilias Plakokefalos is a post-doctoral researcher in the SHARES project at the University of Amsterdam [The research leading to this article has received funding from the European Research Council under the European Union's Seventh Framework Programme (FP7/2007-2013)/ERC grant agreement no. 249499, as part of SHARES, carried out at the Amsterdam Center for International Law (ACIL) of the University of Amsterdam].

Cedric Ryngaert holds the Chair of Public International Law at the School of Law of the Faculty of Law, Economics and Governance at Utrecht University [The research leading to this article has received funding from the Dutch Organization for Scientific Research-NWO]. 